\title{
Analisis Kemampuan Berpikir Kritis Siswa Tentang Materi Larutan Elektrolit dan Non Elektrolit
}

\author{
Analysis of Critical Thinking Skills in Student of Regarding Electrolyte and Non- \\ Electrolyte Solutions Material
}

\author{
R. K. Ningrum*, Ratman \\ Jurusan Pendidikan MIPA, Fakultas Keguruan dan Ilmu Pendidikan Universitas Tadulako \\ *e-mail: reginakristi24@gmail.com
}

\begin{tabular}{l}
\hline Article Info \\
\hline Article History: \\
Received: 7 July 2021 \\
Accepted: 31 October 2021 \\
Published: 3 November 2021 \\
Keywords: \\
Critical thinking skills, \\
Electrolyte \\
Non-electrolyte Solutions \\
\end{tabular}

\begin{abstract}
The purpose of this study was to describe students' critical thinking skills on the material of Electrolyte and Non-Electrolyte Solutions in class X SMA Negeri 6 Sigi. This type of research was descriptive quantitative. In the learning process, the teacher used Google Drive and the Whatsapp application as online learning media. The data collected was the form of critical thinking ability test results that obtained through giving questions in the form of online essays. Furthermore, the data were collected and analyzed based on indicators of critical thinking skills which including interpretation, analysis, inference, and evaluation. The results of data analysis on critical thinking skills of students of class X MIA 1 on the indicators of interpretation, analysis, inference, and evaluation were $51 \%, 41 \%, 42 \%$, and $47 \%$, respectively. The average result for all indicators of critical thinking ability of students in class X MIA 1 was 45\%. For class X MIA 2, 51\%, 39\%, 36\% and $41 \%$ respectively. Overall, the results of the critical thinking skills of class $X$ student was $43.5 \%$. This result shows that the critical thinking ability of students in the class X SMA Negeri 6 Sigi was in a low category.
\end{abstract}

\section{PENDAHULUAN}

Pendidikan dipandang sebagai sarana untuk melahirkan insaninsan yang cerdas, kreatif, terampil, bertanggung jawab, produktif dan berbudi pekerti luhur. Pendidikan bertujuan untuk membantu para siswa dalam mengembangkan potensi yang dimilikinya. [1] Peningkatan kualitas pendidikan dapat dilakukan dengan cara peningkatan sarana prasarana, peningkatan mutu para pendidik, peningkatan mutu peserta didikk, penyempurnaan sistem penilaian, penataan organisasi dan manajemen pendidikan serta usaha-usaha lain yang berkenaan dengan peningkatan kualitas pendidikan. [2]

Kemampuan berpikir kritis merupakan kemampuan yang penting untuk dimiliki siswa agar siswa dapat memecahkan persoalan-persoalan yang dihadapi dalam dunia yang senantiasa berubah. [3] Berpikir adalah suatu kegiatan akal untuk mengolah pengetahuan yang kita terima melalui pancaindra dan ditunjukkan untuk mencapai suatu kebenaran dan istilah berpikir dipergunakan untuk menunjukkan suatu bentuk kegiatan akal yang terarah. [4] Ini artinya bahwa dalam berpikir seseorang melakukan kegiatan akal guna mencari suatu kebenaran dengan diperoleh melalui berbagai pancaindra yang digunakannya. [5]

Kata kritis berasal dari bahasa Yunani yaitu kritikos dan criterion [6] Kata kritikos berarti 'pertimbangan' sedangkan criterion mengandung makna 'ukuran buku' atau 'standar. Sehingga etimologi, kata kritis mengandung makna 'pertimbangan yang didasarkan pada suatu ukuran buku atay standar'. Dengan demikian secara etimologi berpikir kritis mengandung makna suatu kegiatan mental yang dilakukan seseorang untuk dapat memberi pertimbangan dengan menggunakan ukuran atau stadar tertentu.

Menurut ennis dalam Fisher [7], berpikir kritis adalah pemikiran yang masuk akal dan reflektif yang berfokus untuk memutuskan apa yang mesti dipercaya atau dilakukan. Jadi, dengan melatih kemampuan berpikir kritis siswa, diharapkan siswa dapat memutuskan langkah-langkah yang tepat untuk menyelesaikan permasalahan-permasalahan yang mereka hadapi.

Keterampilan berpikir kritis merupakan kemampuan berpikir tingkat tinggi. Keterampilan berpikir kritis adalah kemampuan berpikir dalam membuat keputusan yang dapat dipercaya dan bertanggung jawab Keterampilan berpikir kritis 
berpengaruh terhadap kemampuan seseorang dalam menyelesaikan masalah dalam kehidupan sehari-hari. [8]

Menurut Facione [9], ada enam kecakapan berpikir kritis utama yang terlibat didalam proses berpikir kritis. Kecakapankecakapan tersebut adalah terpretasi, analisis, evaluasi, inference, penjelasan dan regulasi diri. Berikut adalah deskripsi dari keenam kecakapan berpikir kritis utama:

\section{(1) Interpretasi}

Menginterpretasi adalah memahami dan mengekspresikan makna atau signifikasi dari berbagai macam pengalaman, situasi, data, kejadian-kejadian, penilaian, kebiasaan, atau adat, kepercayaankepercayaan, aturan-aturan, prosedur atau kriteriakriteria.

(2) Analisis

Analisis adalah mengidentifikasi hubungan-hubungan inferensial yang dimaksud dan aktual diantara pernyataanpernyataan, pertanyaan-pertanyaan, konsep-konsep, deskripsi-deskripsi atau bentuk-bentuk representasi lainnya yang dimaksud untuk mengekspresikan kepercayaan-kepercayaan, penilaian, pengalamanpengalaman, alasan-alasan, informasi atau opini-opini.

\section{(3) Inferensi}

Inferensi berarti mengidentifikasi dan memperoleh unsurunsur yang diperlukan untuk membuat kesimpulankesimpulan yang masuk akal, membuat dugaan-dugaan dan hipotesis, mempertimbangkan informasi yang relevan dan menyimpulkan konsekuensi-konsekuensi dari data, situasi-situasi, pertanyaan-pertanyaan atau bentuk-bentuk representasi lainnya.

\section{(4) Evaluasi}

Evaluasi adalah menaksir kredibilitas pernyataanpernyataan atau representasi-representasi yang merupakan laporan-laporan atau deskripsi-deskripsi dari persepsi, pengalaman, penilaian, opini, dan menaksir kekuatan logis dari hubungan-hubungan inferensional atau dimaksud diantara pernyataan-pernyataan, deskripsi-deskripsi, pertanyaan-pertanyaan atau bentuk-bentuk representasi lainnya.

\section{(5) Penjelasan}

Penjelasan menyatakan hasil-hasil dari penjelasan seseorang, mempresentasikan penalaran seseorang dalam bentuk argumen-argumen yang kuat.

\section{(6) Regulasi diri}

Regulasi diri berarti secara sadar diri memantau kegiatankegiatan kognitif seseorang, unsur-unsur yang digunakan dalam kegiatan-kegiatan tersebut dan hasil-hasil yang diperoleh, terutama dengan menerapkan kecakapankecakapan didalam analisis dan evaluasi untuk penelitian penilaian inferensial sendiri dengan memandang pada pertanyaan, konfirmasi, validasi atau mengoreksi baik penalarannya atau hasil-hasilnya.

Keterampilan berpikir kritis sangat penting untuk diajarkan dan dilatihkan sedini mungkin secara terus menerus sesuai dengan usia dan tahapan perkembangan peserta didik sehingga peserta didik mampu mencermati berbagai persoalan belajar yang mungkin terjadi dalam kegiatan pembelajaran dan memikirkan solusi dari permasalahan tersebut sehingga hasil belajar yang baik dapat terwujud, bahkan persoalan dalam kehidupan yang dilalui pada setiap tahapan perkembangan peserta didik dapat diatasi dengan kemampuan mencari solusi dari permasalahan berdasarkan pengalaman belajar yang telah dilalui. [10]

Dengan demikian, pengembangan kemampuan berpikir, baik perpikir kritis merupakan suatu hal yang penting untuk dilakukan dan perlu dilatihkan pada siswa mulai dari jenjang pendidikan dasar sampai jenjang pendidikan menengah, berpikir kritis dalam pendidikan kimia dibutuhkan karena memiliki peran yang sangat dominan dalam mendidik siswa, contohnya adalah kemampuan untuk mengelolah informasi agar bisa kompetitif dalam proses belajar mengajar kimia. [11] Pembelajaran kimia pada umumnya menuntut siswa untuk mempelajari konsep-konsep ilmu kimia maupun materi kimia yang bersifat hitungan matematis. Dalam proses pembelajaran kimia, kemampuan berpikir kritis siswa dapat dilihat dari bagaimana siswa menyikapi setiap permasalahan kimia yang ada. [12]

Hasil wawancara terhadap salah seorang guru kimia di SMA Negeri 6 Sigi juga diperoleh bahwa salah satu masalah dalam proses pembelajaran di kelas adalah kurangnya kemampuan berpikir kritis pada siswa. Guru kurang menciptakan kondisi dan situasi yang memungkinkan siswa untuk berpikir kritis dalam proses pembelajaran. Ditambah lagi saat ini mereka sedang menggunakan pembelajaran daring, dikarenakan pandemi covid-19. Dimana guru hanya menggunakan media internet untuk dapat mengajar. Pada kenyataannya proses pembelajaran daring banyak membuat siswa bosan dan ditambah lagi kurangnya fasilitas yang ada dirumah untuk belajar sistem online. Belum lagi siswa atau keluarganya yang tidak memiliki ponsel pintar (smartphone). Pembelajaran dengan mekanisme online sangat sulit karena, kebanyakan mereka tidak paham dengan ilmu teknologi informasi (IT) saat memberikan tugas atau paparan pendidikan ke siswa, itu yang membuat guru ataupun siswa merasa kesulitan dalam proses pembelajaran online. Apalagi setiap tugas harus dipersiapkan setiap harinya.Pembelajaran lebih banyak bersifat teoritis dan minim praktik karena tidak dimugkinkan adanya interaksi langsung dengan siswa.Selain itu, jangkauan internet yang tidak stabil, tentunya akan sulit bagi siswa maupun guru untuk mengakses layanan pembelajaran daring. Beberapa siswa mungkin dapat menangkap materi dengan baik, namun ada juga siswa yang membutuhkan waktu lebih lama sampai benar-benar paham.Hal ini semakin membuat rendahnya kemampuan berpikir kritis siswa di SMA Negeri 6 Sigi. Kurangnya kemampuan berpikir kritir siswa pada materi kimia akan berdampak pada nilai yang diperoleh siswa. Hal ini dapat dilihat dari data ujian semester ganjil kelas $\mathrm{X}$ pada tahun 2019/2020 dimana masih ada beberapa siswa yang mendapatkan nilai dibawah kriteria ketuntasan minimal (KKM). 
Istilah daring merupakan akronim dari "dalam jaringan" yaitu suatu kegiatan yang dilaksanakan dengan sistem daring yang memanfaatkan internet. Menurut Bilfaqih \& Qomarudin [13] "pembelajaran daring merupakan program penyelenggaraan kelas pembelajaran dalam jaringan untuk menjangkau kelompok target yang masif dan luas". Thorme dalam Kuntarto [14] "pembelajaran daring adalah pembelajaran yang menggunakan teknologi multimedia, kelas virtual, CD ROM, streaming video, pesan suara, email dan telepon konferensi, teks online animasi, dan video streaming online". Sementara itu Rosenberg dalam Alimuddin, Tawany \& Nadjib [15] menekankan bahwa e-learning merujuk pada penggunaan teknologi internet untuk mengirimkan serangkaian solusi yang dapat meningkatkan pengetahuan dan keterampilan.

Pengertian di atas, dapat disimpulkan bahwa pembelajaran daring atau e-learning merupakan suatu pembelajaran yang memanfaatkan teknologi dengan menggunakan internet dimana dalam proses pembelajarannya tidak dilakukan dengan face to face tetapi menggunakan media elektronik yang mampu memudahkan siswa untuk belajar kapanpun dan dimanapun.

Dari penjelasan di atas maka kelebihan dan kekurangan dari pembelajaran daring atau e-learning yaitu mempermudah proses pembelajaran, pembelajaran dapat dilakukan dimana saja, mudahnya mengakses materi, melatih pembelajar lebih mandiri, serta pengumpulan tugas secara online. Tetapi ada juga kekurangan dari pembelajaran daring/e-learning yaitu tidak adanya pengawasan karena pembelajaran dilaksanakan secara face to face, jika peserta didik tidak mampu belajar mandiri dan motivasi belajarnya rendah, maka ia akan sulit mencapai tujuan pembelajaran serta kurangnya pemahaman terhadap materi, serta pengumpulan tugas yang tidak terjadwalkan. [16]

Tujuan penelitian ini adalah untuk "menganalisis kemampuan berpikir kritis tentang materi Larutan Elektrolit Dan Non Elektrolit pada Siswa Kelas X SMAN 6 Sigi”.

\section{METODE}

Jenis penelitian ini adalah penelitian deskriptif kuantitatif [17] yang merupakan suatu karakteristik dari suatu variabel yang nilai-nilainya dinyatakan dalam bentuk numerical.

Penelitian ini dilakukan di SMA Negeri 6 Sigi Kecamatan Palolo, Kabupaten Sigi.

Populasi penelitian ini adalah seluruh siswa kelas X MIA SMA Negeri 6 Sigi yang berjumlah 107 orang dan telah mempelajari materi larutan elektrolit dan non elektrolit. Sampel penelitian terdiri dari 2 kelas yaitu X MIA 1 yang berjumlah 23 orang dan X MIA 2 yang berjumlah 24 orang.
Teknik pengambilan sampel dengan cara random sampling. Dalam hal ini yang menjadi sampel yaitu kelas MIA 1 dan MIA 2.

\section{Instrumen Penelitian}

Instrumen penelitian yang digunakan pada penelitian ini adalah tes kemampuan berpikir kritis yang terdiri dari 5 soal esay, dimana jumlah soal tersebut disusun berdasarkan 4 indikator berpikir kritis. Sebelum digunakan, terlebih dahulu di validasi oleh validator ahli yaitu salah satu dosen program studi pendidikan kimia yang memiliki ahli dibidangnya.

\section{Analisis Data Hasil Penelitian}

Analisis deskriptif digunakan untuk menghitung persentase, rata-rata pencapaian skor pada setiap kategori berpikir kritis. Adapun tahap pengelolahan data yang dapat dilakukan dalam penelitian ini adalah sebagai berikut:

1. Menentukan kategori berpikir kritis pada setiap konsep dengan cara mencocokan nilai yang diperoleh setiap siswa dengan tingkat pencapaian yang ditetapkan berdasarkan rubrik.

2. Memberikan skor mentah pada setiap jawaban siswa berdasarkan rubric penskoran kemmapuan berpikir krtis.

3. Menghitung skor total untuk setiap aspek kemampuan berpikir kritis.

4. Menghitung pesentase penguasaan tes kemmapuan berpikir kritis dengan rumus :

$$
N=\frac{\text { skor penilaian }}{\text { skor maksimum }} \times 100 \%
$$

Dimana:

$N=$ persentasi keterampilan berpikir kritis siswa

Tabel 1. Kategori Persentase Kemampuan Berpikir Kritis

\begin{tabular}{|c|c|}
\hline \multicolumn{2}{|c|}{ [18] } \\
\hline $\begin{array}{c}\text { Tingkat pencapaian } \\
(\%)\end{array}$ & Kategori \\
\hline $85 \leq \mathrm{N}$ & Sangat tinggi \\
\hline $75<\mathrm{N} \leq 85$ & Tinggi \\
\hline $60<\mathrm{N} \leq 75$ & Sedang \\
\hline $40<\mathrm{N} \leq 60$ & Rendah \\
\hline $0<\mathrm{N} \leq 40$ & Sangat Rendah \\
\hline
\end{tabular}

Nilai rata-rata kemampuan berpikir kritis siswa diperoleh dengan rumus:

Rata-rata KBK siswa $=\frac{\sum \text { persentase kemampuan berpikir kritis }}{\sum \text { siswa }}$

5. Menentukan kemampuan berpikir kritis siswa secara individu maupun secara keseluruhan dengan cara menentukan persentase kemmapuan berpikir kritis siswa pada setiap pencapaian kategori.

6. Kategori kemampuan berpikir kritis siswa dinyatakan baik jika tingkat kemampuan berpikir kritis siswa minimal sedang dan tinggi. [19] 
Tujuan dari penelitian ini yaitu untuk menganailis kemampuan berpikir kritis siswa kelas X MIA 1 dan MIA 2 SMA Negeri 6 Sigi pada materi larutan elektrolit dan non elektrolit.

Kemampuan berpikir kritis siswa diukur dari indicator yang di adaptasi dari Facione [9] yaitu interpretasi, analisis, inferensi dan evaluasi.

Data hasil tes kemampuan berpikir kritis siswa kelas $\mathrm{X}$ MIA 1 dan MIA 2 SMA Negeri 6 Sigi pada materi larutan elektrolit dan non elektrolit sebagai berikut:

Tabel 2. Data Hasil Analisis Kemampuan Berpikir Kritis (KBK) Siswa Kelas X MIA 1 SMA Negeri 6 Sigi

\begin{tabular}{cccc}
\hline No. & $\begin{array}{c}\text { Indikator } \\
\text { KBK }\end{array}$ & $\begin{array}{c}\text { \% per } \\
\text { Indikator }\end{array}$ & Kategori \\
\hline 1 & Interpretasi & 51 & Rendah \\
2 & Analisis & 39 & Sangat Rendah \\
3 & Inferensi & 36 & Sangat Rendah \\
4 & Evaluasi & 41 & Rendah \\
\hline
\end{tabular}

Data pada Tabel 2 menunjukkan bahwa presentasi dari indikator interpretasi dan evaluasi berada pada kategori rendah, sedangkan indikator analisis dan inferensi berada pada kategori sangat rendah.

Tabel 3. Data Hasil Analisis Kemampuan Berpikir Kritis (KBK) Siswa Kelas X MIA 2 SMA Negeri 6 Sigi

\begin{tabular}{cccc}
\hline No. & $\begin{array}{c}\text { Indikator } \\
\text { KBK }\end{array}$ & $\begin{array}{c}\text { \% per } \\
\text { Indikator }\end{array}$ & Kategori \\
\hline 1 & Interpretasi & 51 & Rendah \\
2 & Analisis & 41 & Rendah \\
3 & Inferensi & 42 & Rendah \\
4 & Evaluasi & 47 & Rendah \\
\hline
\end{tabular}

Data pada Tabel 3 menunjukkan bahwa presentasi dari semua indikator baik itu interpretasi, analisis,inferensi dan evaluasi berada pada kategori rendah.

Pengolahan data dari tes kemampuan berpikir kritis diperoleh hasil untuk kelas X MIA 1 skor rata-rata yang di peroleh indikator interpretasi sebesar $51 \%$, selanjutnya indikator analisis sebesar $41 \%$, indikator inferensi sebesar $42 \%$ dan indikator evaluasi sebesar $47 \%$. Berdasarkan data tersebut, range nilai dari setiap indikator termasuk dalam kategori kemampuan berpikir kritis rendah. Sedangkan pada kelas X MIA 2 diperoleh skor rata-rata hasil tes kemampuan berpikir kritis untuk indikator interpretasi sebesar 51\%, indikator analisis sebesar 39\%, indikator inferensi sebesar $36 \%$ dan untuk indikator evaluasi sebesar $41 \%$. Berdasarkan data tersebut, range nilai untuk indikator inferensi dan evaluasi termasuk dalam kategori rendah, untuk indikator analisis dan inferensi termasuk dalam kategori sangat rendah.

Kemampuan interpretasi adalah memahami dan mengekspresikan makna atau signifikasi dari berbagai macam pengalaman, situasi, data, kejadian-kejadian, penilaian, kebiasan,atau adat, kepercayaan-kepercayaan, aturan-aturan, prosedur atau kriteria. [9] Interpretasi diukur agar siswa mampu mengelompokkan, menjelaskan pokok bahasan, dan menjelaskan makna yang terkandung. Data yang terdapat pada Tabel 1 dan Tabel 2 menunjukkan kemampuan berpikir kritis siswa untuk indikator interpretasi pada kelas X MIA 1 dan MIA 2 masih termasuk dalam range rendah dengan skor yang sama sebesar $51 \%$. Dapat di gambarkan bahwa siswa kelas X MIA 1 dan MIA 2 SMA Negeri 6 Sigi belum memiliki kemampuan berpikir kritis dengan baik.Pada langkah ini siswa tidak dapat menuliskan informasi yang diketahui sertatidak dapat menggambarkan kondisi masalah dengan tepat.

Kemampuan analisis merupakan kemampuan mengidentifikasi hubungan-hubungan inferensial yang dimaksud dan aktual diantara pernyataan-pernyataan, pertanyaan-pertanyaan, konsep-konsep, deskripsi-deskripsi atau bentuk-bentuk representasi lainnya yang dimaksud untuk mengekspresikan kepercayaan-kepercayaan, penilaian, pengalaman-pengalaman, alasan-alasan, informasi atau opini. [9] Analisis diukur agar siswa mampu menganalisis pernyataan dan petanyaan. Berdasarkan Tabel 1 dan Tabel 2 pada indikator analisis untuk kelas X MIA 1 diperoleh data sebesar $41 \%$ termasuk dalam range rendah, dan skor untuk kelas X MIA 2 sebesar 39\% yang termasuk dalam range sangat rendah. Dapat di gambarkan bahwa siswa kelas X MIA 1 dan MIA 2 SMA Negeri 6 Sigi belum memiliki kemampuan berpikir kritis dengan baik.Pada langkah ini siswa belum mampu dalam mengidentifikasi hubungan antara semua konsep yang diperlukan dalam menyusun rencana penyelesaian masalah sehingga banyak yang kurang tepat dalam mengidentifikasi hubungan antara informasi, pertanyaan dan semua konsep yang diperlukan untuk menyusun rencana.

Kemampuan inferensi adalah mengidentifikasi dan memperoleh unsur-unsur yang diperlukan untuk membuat kesimpulan-kesimpulan yang masuk akal, membuat dugaandugaan dan hipotesis, mempertimbangkan informasi yang relevan dan menyimpulkan konsekuensi-konsekuensi dari data, situasi-situasi, pertanyaan-pertanyaan atau bentukbentuk representasi lainnya. [9] Inferensi diukur agar siswa mampu membuat kesimpulan dari hasil pengamatan dan menganalisisnya. Tabel 1 dan Tabel 2 menunjukkan kemampuan berpikir kritis siswa kelas X MIA 1 untuk indikator inferensi masih masuk dalam range rendah dengan skor $42 \%$, sedangkan pada siswa kelas X MIA 2 skor yang diperoleh sebesar $36 \%$ dan termasuk range sangat rendah.Berdasarkan data tersebut memberikan gambaran bahwa siswa kelas X MIA 1 dan MIA 2 SMA Negeri 6 Sigi belum memiliki kemampuan berpikir kritis dengan baik. Pada langkah ini siswa kurang mampu membuat kesimpulan sehingga tidak sesuai dengan konteks soal.

Kemampuan evaluasi merupakan menaksir kredibilitas pernyataan-pernyataan atau representasi-representasi yang merupakan laporan-laporan atau deskripsi-deskripsi, mengalaman, penilaian, opini, dan menaksir kekuatan logis dari hubungan inferinsional atau dimaksud diantara pernyataan-pernyataan, deskripsi-deskripsi, pertanyaan atau 
bentuk representasi lainnya. [9] Evaluasi diukur agar siswa mampu menilai kredibilitas dari pernyataan. Tabel 2 dan Tabel 3 menunjukkan hasil data yang diperoleh untuk indikator evaluasi siwa kelas X MIA 1 dan MIA 2 SMA Negeri 6 Sigi masih berada pada range rendah dengan skor kelas X MIA 1 sebesar 47\% dan kelas X MIA 2 sebesar $41 \%$. Berdasarkan data tersebut dapat digambarkan bahwa siswa kelas X Mia 1 dan Mia 2 SMA Negeri 6 Sigi belum memiliki kemampuan berpikir kritis dengan baik.Pada langkah ini siswa kurang mampu menggunakan strategi yang tepat dalam menyelesaikan soal, lengkap dan benar dalam melakukan prosedur pengerjaan.

Merujuk hasil analisis data dapat ditarik kesimpulan bahwa kemampuan berpikir kritis siswa SMA Negeri 6 Sigi masih rendah. Hal ini dikarenakan saat ini siswa SMA Negeri 6 Sigi tengah menerapkan proses pembelajaran daring akibatdari pandemic covid-19 yang melanda seluruh dunia. Dimana dalam proses pembelajaran daring, guru hanya sebatas memberi teks uraian materi kepada siswa yang dibagikan melalui grup disalah satu aplikasi percakapan (Whatssapp) serta guru juga seringkali menggunakan aplikasi Google Drive untuk membagikan tugas kepada siswa. Namun kenyataannya masih banyak siswa yang tidak pro aktif dalam pelaksanaan pembelajaran daring, seringkali mereka lalai dalam mengumpulkan tugas. Tidak adanya pengawasan karena pembelajaran tidak dilaksanakan secara face to face. Jika peserta didik tidak mampu belajar mandiri dan motivasi belajarnya rendah, maka ia akan sulit mencapai tujuan pembelajaran serta kurangnya pemahaman terhadap materi.

Kurangnya efektivitas dalam proses pembelajaran daring juga menjadi salah satu penyebab rendahnya kemampuan berpikir kritis siswa SMA Negeri 6 Sigi. Efektivitas pembelajaran adalah tingkat keberhasilan yang dapat dicapai dari suatu metode pembelajaran tertentu sesuai dengan tujuan pembelajaran yang telah direncanakan.

Seperti yang telah diketahui bahwa kemampuan berpikir kritis dapat dikatakan tercapai apabila siswa telah mencapai kategori sedang atau tinggi pada semua indikator. Para pakar menyatakan bahwa tidak semua orang sepenuhnya berhasil tuntas dalam seluruh keterampilan berpikir kritis karena manusia memilah-milah kehidupan mereka sedemikian rupa sehingga berpikir kritis lebih aktif di beberapa keterampilan kognitif saja tetapi hal ini tidak mengartikan bahwa tidak mungkin untuk dapat berhasil sepenuhnya menguasai keterampilan berpikir kritis jika pengembangan berpikir kritis terus diterapkan dalam pengembangan kurikulum. [20] Berdasarkan hasil penelitian yang dilakukan, siswa yang menjawab salah belum tentu tidak mampu mengembangkan kemampuan berpikir kritis, tetapi bisa saja pengetahuan dasar masih kurang, sehingga siswa tidak dapat menyelesaikan soal yang diujiankan.

\section{KESIMPULAN}

Berdasarkan hasil analisis data penelitian, maka dapat disimpulkan bahwa kemampuan berpikir kritis siswa SMA Negeri 6 Sigi pada materi larutan elektrolit dan non elektrolit masih rendah. Hal tersebut dibuktikan melalui data hasil tes kemampuan berpikir kritis siswa kelas X MIA 1 pada indikator interpretasi, analisis, inferensi dan evaluasi berturutturut sebesar 51\%, 41\%, 42\% dan 47\%. Untuk kelas X MIA 2 berturut-turut sebesar $51 \%, 39 \%, 36 \%$ dan $41 \%$.

\section{UCAPAN TERIMA KASIH}

Penulis mengucapkan banyak terimakasih kepada pihak SMA Negeri 6 Sigi serta semua pihak yang membantu penulis dalam menyelesaikan penelitian ini.

\section{REFFERENSI}

[1] G. Rosarina, A. Sudin, \& A. Sujana, "Penerapan Model Discovery Learning untuk Meningkatkan Hasil Belajar Siswa pada Materi Perubahan Wujud Benda," Jurnal Pena Ilmiah, 1(1), 2016, pp. 371-380.

[2] D. A. Nugraha, E. V. H. Susanti, \& M. Masykuri, "Efektivitas Metode Pembelajaran Kooperatif Think Pair share (TPS) yang Dilengkapi Media Kartu Berpasangan (Index Card Match) terhadap Prestasi Belajar Siswa pada Materi Ikatan Kimia Kelas X Semester Gasal SMAN 2 Karanganyar Tahun Pelajaran 2012/2013," Jurnal Pendidikan Kimia, 2(4), 2013, pp. 174-181.

[3] Kemendikbud, "Permendikbud No. 20 Tahun 2016 Tentang Standar Proses Pendidikan Dasar dan Menengah,” Jakarta : Kemendikbud, 2019.

[4] Departemen Pendidikan Nasional, "Pembelajaran yang Mengembangkan Critical Thinking," Direktorat Jendral Manajemen Pendidikan Dasar dan Menengah Direktorat Pembinaan Sekolah Mengengah Atas, 2009.

[5] F. Nugroho, "Keterampilan Berpikir Kritis Siswa Pada Materi Kesetimbangan Kimia melalui Pembelajaran Berbasis Masalah," Fakultas Ilmu Tarbiyah dan Keguruan Program Studi Pendidikan Kimia, 2009.

[6] Suriadi, "Pembelajaran dengan Pendekatan Discovery yang Menekankan Aspek Anak Logi untuk Meningkatkan Pemahaman Matematik dan Kemampuan Berpikir Kritis Siswa SMA,” Tesis SPs UPI Banndung, 2006.

[7] A. Fhiser, "Berpikir Kritis Sebuah Pengantar", Erlangga, 2009. 
[8] I. W. Redhana, "Model pembelajaran berbasis masalah untuk peningkatan keterampilan pemecahan masalah dan berpikir kritis," Jurnal pendidikan dan pengajaran, 46(1), 2013.

[9] P. Facione, "Critical Thinking: What It Is and Why It Counts," Measured Reasons and The California Academic Press, Millbrae, CA, 2013.

[10] B. Ismayawati, A. A. Purwoko, , \& M. Muntari, "Pengaruh Model Pembelajaran Berbasis Masalah (PBM) dalam Setting Pembelajaran Kooperatif Tipe TGT dan GI terhadap Keterampilan Berpikir Kritis dan Hasil Belajar Kimia Peserta Didik SMAN 1 Aikmel,” Jurnal Penelitian Pendidikan IPA, 2(1), 2016.

[11] S. Hasibuan ,dan E. Surya, "Analysis Of Critical Thinking Skillls Class X SMK Patronage State North Sumatra Province Academic Year 2015/2016," Jurnal Saung Guru. Volume VIII(2), 2016.

[12] D. A. Indraningtias, \& A. Wijaya, "Pengembangan Perangkat Pembelajaran Berbasis Pendekatan Matematika Realistik Materi Bangun Ruang Sisi Datar Berorientasi pada Kemampuan Berpikir Kritis Siswa Kelas VIII SMP,” Jurnal Pendidikan Matematika-S1, 6(5), 2017, 24 36.

[13] Bilfaqih, Y., Qomarudin, M.N., "Esensi Penyusunan Materi Daring untuk Pendidikan Dan Pelatihan," Yogyakarta: DeePublish, 2015.

[14] E. Kuntarto, "Keefektifan Model Pembelajaran Daring Dalam Perkuliahan Bahasa Indonesia Diperguruan Tinggi," Juornal Indonesian Language Education and Literature / ILE\&E/Vol.3(1), 2007.

[15] Alimuddin, Tawany \& Najib, "Intensitas Penggunaan E-Learning Menunjang Pembelajaran Mahasiswa Program Sarjana (S1)," Universitas Hasanudin, 2015.

[16] Hadisi, dan Muna, "Pengelolaan Teknologi Informasi Dalam Menciptakan Model Inovasi Pembelajaran (E-Learning)," Jurnal Al-Ta'dib, 8, 2015, pp. 127-132.

[17] Sugiyono, "Metode Penelitian Kuantitatif Kualitatif dan R\&D,” Bandung: Alfabeta, 2015.
[18] Afadil, Suyono, \& S. Poedjiastoeti, "Practicality of Learning Based on Three Scientific Questions (Model PBTPK) To Increase Critical Thinking Ability And Understanding Thermochemical Concept Of Students," Proceeding International Seminar on Science Education (ISSE) Volume 2, pp. 2476-9533, 2016.

[19] R. Hake, (2002). Relationship of Individual Student Normalizar Learning Gains in Mechanic with Gender, High-School Physics, and Pretest Scores on Mathematic and Spatial Visualization. [online] Tersedia pada : http: www. physycs. indiana. edu/hake.

[20] M. Nur, Nasution., \& J. Suryanti, "Berpikir Kritis," Universitas Negeri Surabaya, 2013. 